IZA DP No. 9823

The Simple Analytics of Job Displacement Insurance

Donald O. Parsons

March 2016 


\title{
The Simple Analytics of Job Displacement Insurance
}

\author{
Donald O. Parsons \\ George Washington University \\ and IZA
}

\section{Discussion Paper No. 9823 \\ March 2016}

\author{
IZA \\ P.O. Box 7240 \\ 53072 Bonn \\ Germany \\ Phone: +49-228-3894-0 \\ Fax: +49-228-3894-180 \\ E-mail: iza@iza.org
}

Any opinions expressed here are those of the author(s) and not those of IZA. Research published in this series may include views on policy, but the institute itself takes no institutional policy positions. The IZA research network is committed to the IZA Guiding Principles of Research Integrity.

The Institute for the Study of Labor (IZA) in Bonn is a local and virtual international research center and a place of communication between science, politics and business. IZA is an independent nonprofit organization supported by Deutsche Post Foundation. The center is associated with the University of Bonn and offers a stimulating research environment through its international network, workshops and conferences, data service, project support, research visits and doctoral program. IZA engages in (i) original and internationally competitive research in all fields of labor economics, (ii) development of policy concepts, and (iii) dissemination of research results and concepts to the interested public.

IZA Discussion Papers often represent preliminary work and are circulated to encourage discussion. Citation of such a paper should account for its provisional character. A revised version may be available directly from the author. 


\section{ABSTRACT}

\section{The Simple Analytics of Job Displacement Insurance*}

Job displacement in the U.S. is a serious threat to the earnings of long-tenured workers, through both (i) unemployment spells and (ii) reduced reemployment wages. Although full insurance requires both unemployment benefits and wage insurance, supply difficulties limit actual-loss insurance, and separation packages typically include partial unemployment insurance and scheduled (fixed sum) severance pay. The design of this two dimensional package requires a systems approach as well as a generalized replacement ratio measure of adequacy). Job search moral hazard and layoff moral hazard (firing costs), individually and in combination, introduce potentially serious contracting concerns. Economic theory provides a practical guide to the integration of these insurance instruments in this complex planning environment. One important implication: given the structure of earnings losses at displacement in the U.S., severance pay should increase with length of service in the firm ("tenure"), which is common, and unemployment insurance benefit levels should fall, which is not.

JEL Classification: J65, J41, J33, J08

Keywords: job displacement, unemployment insurance, wage insurance, severance pay, moral hazard, insurance adequacy, replacement rate

Corresponding author:

Donald O. Parsons

Economics Department

George Washington University

2115 G Street NW, Monroe Hall 368

Washington, DC 20052

USA

E-mail: dopars@gwu.edu

\footnotetext{
* This paper had an unusually long gestation time. Early versions circulated under the titles "Private Job Displacement Insurance: Information Asymmetries and Separation Pay Design" and "DoubleSided Moral Hazard In Job Displacement Insurance Contracts." Detailed comments on early drafts by Bryan Boulier, Timothy Perri, and Torben Tranæs are gratefully acknowledged, as are comments by seminar participants at the Economic Policy Research Unit (EPRU) and the Center for Applied Microeconometrics (CAM), both at the University of Copenhagen; the Korea Labor Institute (Seoul, Korea); the World Bank/IIASA/Ludwig Boltzmann Institute International Workshop on Severance Pay Reform (Laxenberg/Vienna); the U.S. Bureau of Labor Statistics; George Washington University; and Ohio University.
} 


\section{Introduction}

Earnings losses following job displacement are large for long-tenured workers in the United States and similar economies (Canada and the United Kingdom). ${ }^{1}$ These losses arise from a combination of unemployment spells and lower wages on the next, reemployment job. Of the long-tenured (three or more years of service) workers in the 2012 Displaced Workers Survey displaced between 2009 to 2011, only 56 percent were employed in January of 2012 , with another 26.7 percent unemployed and the remainder (17.4 percent) out of the labor force altogether, BLS (2012). Post-displacement employment prospects drop sharply with age (and presumably years of service), Figure 1, Panel A. For the reemployed, expected wage losses upon reemployment are also substantial and strongly tied to job tenure. Farber (2004), analyzing various Displaced Worker Surveys (DWS), found a systematic, positive relationships between the earnings losses of reemployed workers and the years of service (or tenure) of the worker, Figure 1, Panel B. Losses increase systematically with job tenure: $3.4 \%$ at 1 to 3 years of tenure, $10.1 \%$ at 4 to 10 , 20.5 percent at 11 to 20 , and $28.1 \%$ at greater than $20 .^{2}$

\section{$<$ Figure 1>}

Consumption studies indicate that these large losses for long-tenured workers are poorly insured. This is not because the risks are unknown or unattended to. In the U.S. the workforce is covered by public unemployment insurance and often by employer-provided severance pay. Internationally, mandated severance pay is pervasive as is government supplied unemployment insurance elsewhere in the industrialized world, Holzmann et al (2012). This study highlights the importance of treating unemployment insurance and severance pay as an integrated job separation benefit package. ${ }^{3}$

\footnotetext{
1 Surveys of the U.S. displacement loss literature include Jacobson, LaLonde, and Sullivan (1993a,b), Fallick (1996), Kletzer (1998), and Farber (2004, 2011). See the contributions in Kuhn (2002) for an international perspective.

2 All values converted to percentage change from differences in natural logs in the original.

3 Parsons (2015) provides an overview of job displacement insurance, including a review of relevant consumption studies.
} 
The early employment contracting literature considered severance pay as an alternative to unemployment insurance in second-best contracts, Baily (1977), but severance pay also arises as scheduled wage insurance. The full job displacement insurance design question does not arise in many optimal unemployment insurance studies: (i) because the models ignored reemployment altogether, presumably in order to focus on unemployed status, or (ii) because reemployed workers were assumed to receive wage offers equal to those in the displacing job. ${ }^{4}$

In order to develop a deeper understanding of the coordination of the two primary instruments (unemployment benefits and severance pay), a single period contracting model is employed. ${ }^{5}$ A plausible outline of the first-best package is straight-forward and requires little formal motivation-severance pay serves as wage insurance, covering the expected earnings losses (reemployment earnings less prior earnings), while unemployment insurance covers the loss of reemployment earnings during the unemployment spell. ${ }^{6}$ In the model developed below, with additively separable state utility functions (in consumption and leisure), insurance will be complete in the absence of administration costs and information problems. $^{7}$

The literatures on unemployment insurance and severance pay have focused on asymmetric information problems. The unemployment insurance literature has concentrated on search moral hazard concerns--the need to induce workers to search appropriately and reveal the receipt of job offers in this model. ${ }^{8}$ The severance pay (mandates) literature has

\footnotetext{
${ }^{4}$ Again see the general discussion in Parsons (2015).

${ }^{5}$ Reviews of the employment contracting literature include Parsons (1986), Malcomson (1999), and Salanié (2005).

${ }^{6}$ Full reemployment wage insurance would require pooling of the earnings of the winners and the losers, but this has not been seriously proposed. Most policy designers propose a negative option payment-for those who make losses, some fraction of the losses will be paid through premiums from all, Baily, Burtless, and Litan (1993). For additional discussions, see Parsons (2000), Kling (2006), and LaLonde (2007).

7 Parsons (2016) provides a discussion of alternative utility functions and their implications.

8 Excellent reviews of the optimal unemployment insurance literature include Karni (1999), Holmlund (1998), and Fredriksson and Holmlund (2006).
} 
focused on "firing cost" problems, or what will be labeled here "layoff moral hazard". ${ }^{9}$ Search moral hazard is linked with unemployment benefits, but layoff moral hazard is a more general, purely financial consideration that requires additional discussion. If the firm is the insurer of job separation and simultaneously is the only agent with reliable information on its own labor demand conditions, it has an incentive to misreport business conditions if job separation costs are onerous. Most severance plans are designed as government mandates of private firm provision and immediately raise layoff-moral-hazard concerns as do voluntarily provided severance plans. Because most unemployment insurance systems are government operated, with no user cost elements, such systems raise no layoff moral hazard concerns, although the U.S., with substantial experience rating of benefits, is an exception. Clearly both moral hazard issues may affect job displacement insurance systems.

The paper proceeds as follows. The single-period contracting model of job displacement insurance is first introduced, and the first-best (full information) contract derived; the distinct roles of wage insurance and unemployment insurance in the ideal layoff contract emerge. Not surprisingly, the ideal contract is sensitive to reemployment market characteristics. The two dimensional system requires a generalized replacement rate measure of insurance adequacy, not one solely based on the ratio of unemployment benefits to pre-unemployment wages.

The search moral hazard problem and contract adaptions to it are then introduced in Section III. The need to induce revelation of private information on job offer receipt naturally leads to restrictions on the generosity of unemployment insurance and the expansion of severance pay, as Baily (1977) conjectured. The position of this wedge between unemployment benefits and reemployment wages is shown to vary across the business cycle relative to the wages of retained workers in an intuitive way. The impact on the layoff

\footnotetext{
9 The empirical firing cost literature is voluminous. Buechtemann (1992) provides an accessible introduction to the debate. See Heckman and Pages (2004) and Parsons $(2012,2013)$ for recent reviews.
} 
contract terms (and likelihood of guaranteed employment contracts) of layoff moral hazard is developed in Section IV, and the dual moral hazard model-the contract that emerges if both search and layoff moral hazard are present-in Section V. The impact of market conditions and information access on optimal program design is illustrated with a numerical example in Section VI. The theory, combined with the empirical regularities on job displacement earnings losses, generates a guide for designing job displacement packages, Section VII. Section VIII concludes.

\section{A Full Information Model of Private Job Displacement Insurance}

Consider the ideal employment contract. Under the assumption of full information and risk-averse workers, risk-neutral, profit-maximizing firms will release workers if and only if it is efficient to do so, and will supply the ideal insurance package if it is. Consider a single period model ${ }^{10}$ with homogeneous workers and two types of firms/jobs: (i) one that requires substantial advance planning, which will be called the contract market, and (ii) one that does not, the spot market. At the beginning of the period, workers are free to choose jobs, contract or spot. Planning has its rewards and the worker's maximum productivity in the contract market is higher than in the spot market. However, employment in the contract market is not without risk; the contract market is subject to the possibility of a negative demand shock. The size of this shock is fixed to the firm (although it may vary across industries and occupations). The contract employer can, of course, cushion the impact of earnings loss on worker consumption and will have an incentive to do so if administrative costs are small. The nature of the employment contract will be a function of these factors and also of the distribution of information across agents.

The value of a worker's product within the contracting firm is a random variable, which depends on the state of product demand. For simplicity assume only two mutually

\footnotetext{
10 Azariadis (1975), Rosen (1985), and Blanchard and Tirole (2008), among others, employ single period models.
} 
exclusive and exhaustive demand states, $S_{i}, i=1,2$, with a probability $\rho$ that $S_{1}$ will occur. ${ }^{11}$ Label $S_{1}$ and $S_{2}$ as the high-demand (good) state and low-demand (bad) state respectively. Productivities in the contract firm in the two states are:

$\begin{array}{lcl}\text { State } & \text { Probability } & \text { Productivity } \\ \mathrm{S}_{1}: & \rho & v, \quad v>0 \\ \mathrm{~S}_{2}: & 1-\rho & \theta v, 0 \leq \theta<1 .\end{array}$

An independent spot market exists. Denote the spot market (and reemployment) job offer by $W^{R}$. Spot market jobs are available to a subset of displaced workers who must hastily explore the spot market after learning of a contract firm's layoff decision. Denote the probability of receiving a spot market job offer $W^{R}\left(W^{R}<v\right)$ following displacement from a contract job by $\varphi, 0 \leq \varphi \leq 1$.

The worker is assumed (i) to be an expected utility maximizer, (ii) to have an additively separable utility function in consumption and leisure, (iii) to be risk averse in consumption, and (iv) to face a dichotomous (zero-one) work choice. The worker's utility function can then be represented by:

$$
\begin{array}{ll}
U=u(C) & \text { if employed, } \\
U=u(C)+\ell, \ell>0 ; & \text { if unemployed, }
\end{array}
$$

where $u(C)$ is an increasing, concave function. This specification implies that workers facing a costless, competitive insurance market will equalize consumption across states, which of course implies that the worker is better off in the layoff state because of the additional leisure. ${ }^{12}$ Assets and debts are zero by assumption, and consumption in this single period model therefore is equal to income. Worker risk is a function of the variability of productivity in the firm, the state of labor market demand external to the firm

\footnotetext{
${ }^{11}$ Azariadis (1975) considers a set of productivity outcomes, Rosen (1985) a continuum, but these do not affect the basic structure of the insurance schemes and add substantially to the complexity of the model. The firm size issue embedded in these models is also ignored here.

12 This utility structure is used, for example, in Shavell and Weiss (1979) and Hopenhayn and Nicolini (1997). Again see Parsons (2016) for a discussion of alternative utility functions and their implications.
} 
(reemployment probabilities and reemployment wage), and of course the contract the worker and firm negotiate to moderate contingencies.

Two distinct contract forms may be offered in this environment by the firm:

\section{GUARANTEED EMPLOYMENT (GE) \\ LAYOFF WITH SEPARATION BENEFITS (LAYOFF)}

The GE contract requires specification of wages in both high and low demand states $\left(W_{1}\right.$, $\left.W_{2}\right):$

\begin{tabular}{|l|c|c|c|}
\hline $\begin{array}{c}\text { GE } \\
\text { CONTRACT }\end{array}$ & & & \\
\hline \multicolumn{1}{|c|}{ STATE } & PROB. & PROD. & CONSUMPT $_{\mathrm{j}}$ \\
\hline $\mathrm{i}=$ & & & \\
\hline $\begin{array}{l}1 \text { (retained, } \\
\text { good state) }\end{array}$ & $\rho$ & $v$ & $W_{1}$ \\
\hline $\begin{array}{l}\text { 2 (retained, } \\
\text { bad state) }\end{array}$ & $1-\rho$ & $\theta v$ & $W_{2}$ \\
\hline & & & \\
\hline
\end{tabular}

If the contracting firm retains workers in the low demand state as well as the high (the GE contract), the firm's expected profits $(\pi)$ are:

$$
E(\pi)=\rho\left[v-W_{1}\right]+(1-\rho)\left[\theta v-W_{2}\right] \quad(\mathrm{GE})
$$

The LAYOFF contract requires specification of the wage in the high demand state $\left(W_{1}\right)$ and the separation package in the low. The separation package is characterized by the vector $(B, b)$, where again $B$ denotes lump sum severance benefits and $b$ denotes unemployment-conditioned benefits. In this model, contract workers end up in one of three circumstances: (1) retained by the contracting firm, (2) laid off with a reemployment job offer $W^{R}$, or (3) laid off with no job offer (unemployed). If the job offer is accepted, outcome probabilities, worker productivities, and consumption under LAYOFF contracts are:

\begin{tabular}{|l|c|c|c|}
\hline $\begin{array}{c}\text { LAYOFF } \\
\text { CONTRACT }\end{array}$ & & & \\
\hline OUTCOME & PROB. & PROD. & CONSUMPT $_{\mathrm{j}}$ \\
\hline $\mathrm{j}=$ & & & $W_{1}$ \\
\hline 1 (retained) & $\rho$ & $V$ & $B+W^{R}$ \\
\hline $\begin{array}{l}2 \text { (layoff, } \\
\text { reemployed) }\end{array}$ & $(1-\rho) \varphi$ & $W^{R}$ & $B+b$ \\
\hline $\begin{array}{l}3 \text { (layoff, not } \\
\text { reemployed) }\end{array}$ & $(1-\rho)(1-\varphi)$ & 0 & \\
\hline
\end{tabular}


If the firm retains workers only in the good state (LAYOFF), the firm's expected profits are:

$$
E(\pi)=\rho\left[v-W_{1}\right]-(1-\rho)[B+(1-\varphi) b] .{ }^{13} \quad(\text { LAYOFF })
$$

In the analysis to follow, optimal contract features will be characterized by maximization of worker expected utility for a given level of expected profits.

The full information insurance outcome is intuitive in these simple contracts with state independent utility functions. In both the GE and LAYOFF contracts, the worker and the firm negotiate an employment contract that offers the worker complete consumption insurance. Under the GE contract, worker consumption in the two demand states will be equal. Under the zero (expected) profit constraint:

$$
C_{i}=W_{i}=\bar{I}, \quad i=1,2 .
$$

where $\bar{I}=\rho v+(1-\rho) \theta v$, the worker's expected productivity if employed in both states.

The optimal LAYOFF contract will also smooth consumption perfectly across outcomes:

$$
C_{j}=\overline{\bar{I}}, j=1,2,3
$$

where $\overline{\bar{I}}=\rho v+(1-\rho) \varphi W^{R}$, the worker's expected productivity under the assumption that she works when jobs are offered. The optimal LAYOFF consumption plan can be implemented by the following contract terms:

$$
\begin{aligned}
& W_{1}^{*}=\overline{\bar{I}} . \\
& b^{*}=W^{R}, \text { and } \\
& B^{*}=\overline{\bar{I}}-W^{R} .
\end{aligned}
$$

Note the distinct roles played by unemployment insurance and severance benefits. In this framework: severance benefits cover the reemployment wage losses common to all displaced workers, unemployed or reemployed, and unemployment insurance payments

${ }^{13}$ Wages in the good state $\left(\mathrm{W}_{1}\right)$ will of course differ in the two contracts. 
cover the additional losses by workers who cannot find reemployed. The severance benefit is essentially (scheduled) wage insurance.

The two dimensions of JDI benefits require a generalized replacement rate measure of program adequacy. The traditional UI replacement rate measure,

$$
R R(U I)=\frac{b}{W_{1}} * 100 \%
$$

Is less than one hundred percent in the ideal package as long as the displaced worker faces any reemployment wage losses. The generalized replacement rate measure would be:

$$
R R(J D I)=\frac{C_{3}}{C_{1}} * 100 \%=\frac{B+b}{W_{1}} * 100 \%,
$$

and will be one hundred percent in the first best contract under this utility assumption. ${ }^{14}$

The efficient contract form, GE or LAYOFF, will of course depend on which is valued most highly by the worker. The worker will uniquely prefer the GE contract if:

$$
\omega \equiv u\left(C^{*}\right)-u\left(C^{* *}\right)-(1-\rho)(1-\varphi) \ell>0,
$$

where

$$
\begin{aligned}
& C^{*}=\rho v+(1-\rho) \theta v \equiv \bar{I}, \text { and } \\
& C^{* *}=\rho v+(1-\rho) \varphi W^{R} \equiv \overline{\bar{I}} .
\end{aligned}
$$

Equations (6) and (7) represent consumption in the first-best model in the GE and LAYOFF contracts respectively. Inspection of Equations (5)-(7) reveals that the GW contract will be preferred (i) the smaller the productivity contraction in the low demand state (the larger $\theta$ ), (ii) the lower the reemployment wage $W^{R}$, and (iii) the less valued is leisure time $(\ell) .{ }^{15}$ Simple differentiation reveals that increasing the probability of being reemployed if laid off $(\varphi)$ will decrease the likelihood of choosing the GE contract-assuming only that the worker would choose to work for the reemployment wage if offered.

\footnotetext{
14 In a multi-period model, lump sum severance payments should be amortized over the work life.

15 Note the parallels to Azariadis' discussion of the likelihood of layoff $(1975,1193-1194)$.
} 
The firing cost literature places great emphasis on the excessive retention of contract workers in the bad state, or labor hoarding. "Excessive labor hoarding" or employment protection is defined here as worker attachment to the contract firm in excess of that in the first-best contract. The extent of labor hoarding will be indexed by the range of reemployment probabilities over which GE contracts dominate LAYOFF contracts. Excess labor hoarding in the full information case is zero by definition.

\section{Private (Worker) Information, Reemployment Job Offers, and Search Moral Hazard}

Employers are likely to find information on separated workers, especially on subsequent job search and information acceptance, costly to collect. Consider the situation in which:

Asymmetry Assumption 1: The firm can observe post-separation employment activity, but not job offer arrivals.

Asymmetry Assumption 1 is familiar in the public unemployment insurance literature, in which the government is presumed to be able to monitor actual work activity, but not job offers, which workers may strategically ignore. ${ }^{16}$

Under the first best LAYOFF contract, the worker has no incentive to reveal employment offers; income is the same and leisure less with a return to work. If the employer is to induce the worker to reveal truthfully the arrival of wage offers, the separation pay package must insure that the displaced worker is motivated to accept any wage offers she receives. This requires an Offer Revelation Constraint (ORC):

$$
u\left(C_{2}\right) \geq u\left(C_{3}\right)+\ell
$$

where $C_{2}=B+W^{R}$ and $C_{3}=B+b$.

The relevant Lagrangian $(\mathcal{L})$ for the second-best ORC LAYOFF contract is conveniently optimized in consumption form:

16 Search effort, not modeled here, is of course also vulnerable to moral hazard. 


$$
\begin{aligned}
& \mathcal{L}=\rho u\left(C_{1}\right)+(1-\rho) \varphi u\left(C_{2}\right)+(1-\rho)(1-\varphi)\left\{u\left(C_{3}\right)+\ell\right\} \\
& -\lambda\left\{\rho C_{1}+(1-\rho) \varphi C_{2}+(1-\rho)(1-\varphi) C_{3}-\rho v-(1-\rho) \varphi W^{R}\right\} \\
& \quad-\mu\left[\left\{u\left(C_{3}\right)+\ell\right\}-u\left(C_{2}\right)\right] .
\end{aligned}
$$

with respect to $C_{1}, C_{2}, C_{3}, \lambda$, and $\mu(\mu \geq 0)$. The resulting first order conditions for an interior solution are:

$$
\begin{aligned}
& u^{\prime}\left(C_{1}\right)-\lambda=0 \\
& (1-\rho) \varphi\left[u^{\prime}\left(C_{2}\right)-\lambda\right]+\mu u^{\prime}\left(C_{2}\right)=0 \\
& (1-\rho)(1-\varphi)\left[u^{\prime}\left(C_{3}\right)-\lambda\right]-\mu u^{\prime}\left(C_{3}\right)=0 \\
& -\left[\rho C_{1}+(1-\rho) \varphi C_{2}+(1-\rho)(1-\varphi) C_{3}-\rho v-(1-\rho) \varphi W^{R}\right]=0 \\
& -\left[\left\{u\left(C_{3}\right)+\ell\right\}-u\left(C_{2}\right)\right] \geq 0 . \\
& \mu \geq 0, \quad \mu \cdot\left[\left\{u\left(C_{3}\right)+\ell\right\}-u\left(C_{2}\right)\right]=0 .
\end{aligned}
$$

It is trivial to prove that the work constraint is binding if it is rational to have the displaced worker accept a job offer, so that $(10 \mathrm{e})$ can be treated as an equality constraint. The ideal is equal consumption across states, and the limitation on unemployment benefits should therefore be as small as feasible.

Combining 10a-10c yields an important redistributive principle common in this class of problems, ${ }^{17}$

$$
\frac{1}{u^{\prime}\left(C_{1}\right)}=\frac{\varphi}{u^{\prime}\left(C_{2}\right)}+\frac{1-\varphi}{u^{\prime}\left(C_{3}\right)}
$$

The inverse of the marginal utility of consumption in the no-layoff state equals the weighted average of the inverses of the marginal utilities in the two layoff states, with the weights the probability of receiving a job offer if laid off. The redistributive principle leads to the important proposition that:

\footnotetext{
${ }^{17}$ See for example Parsons (1996) and Viard (2001).
} 
Proposition 1: Under ORC, if it is optimal to accept a reemployment job offer, the ORC LAYOFF contract will be characterized by

$$
C_{3} \leq C_{1} \leq C_{2} \text {, with } C_{3}=C_{1} \text { iff } \varphi=0 \text { and } C_{2}=C_{1} \text { iff } \varphi=1 .^{18}
$$

The work/no-work consumption differential is met by an increase in consumption if laid off and reemployed $\left(C_{2}\right)$ and a decrease in consumption if laid off and unemployed $\left(C_{3}\right)$ relative to the retained (good) state $\left(C_{1}\right)$. The firm, like public authorities, must limit the generosity of unemployment benefits if it is to induce the worker to reveal the existence of a wage offer. The contract terms can then be solved recursively for $W_{1}\left(=C_{1}\right), B\left(=C_{2}-W^{R}\right)$, and $b\left(=C_{3}-B\right)$.

The optimizing values are easily solved in explicit form for the logarithmic utility function. Consider a logarithmic consumption utility function:

$$
\begin{array}{ll}
U=\ln (C) & \text { if employed; } \\
U=\ln (C)+\ell, \ell>0 . & \text { if unemployed. }
\end{array}
$$

Consumption across outcomes takes the form:

$$
\begin{array}{ll}
C_{1}=\overline{\bar{I}}, & \text { (Retained) } \\
C_{2}=\frac{e^{\ell \overline{\bar{I}}}}{\varphi e^{\ell}+(1-\varphi)}, \text { and } & \text { (Laid off but reemployed) } \\
C_{3}=\frac{\overline{\bar{I}}}{\varphi e^{\ell}+(1-\varphi)}, & \text { (Laid off and unemployed) }
\end{array}
$$

where $\overline{\bar{I}}=\rho v+(1-\rho) \varphi W^{R}$, the worker's expected total earnings if he accepts reemployment wage offers if laid off. To insure that workers will accept reemployment job offers, the utility of the reemployed must be no less than that of the unemployed despite the greater leisure potentially available to the unemployed. That means that consumption in the reemployed state must exceed that in the unemployed state. 18 The ORC layoff contract will of course not be observed below a critical $\varphi$ level: the GE contract will
be preferred. 
The location of this consumption wedge between the unemployed and the reemployed varies with the economic environment. For example, if the prospects for reemployment are low, virtually all laid off workers will remain unemployed, and the wedge requirement will be optimally met by subsidizing reemployment of the few who succeed in finding jobs, with the unemployed receiving benefits equivalent to what they would have received if retained (the generalized replacement rate for the unemployed will approach one hundred percent, that for the reemployed will be in excess of $100 \%$ ). Conversely, if the prospects for reemployment are extremely high, virtually all laid off workers will receive job offers and the wedge requirement is optimally met by providing the reemployed with consumption equivalent to what they would have receive if retained. The unemployed will receive less support, but there are few of them. As the likelihood of being reemployed increases, the consumption of the unemployed in the search moral hazard contract will fall.

These consumption outcomes can be implemented by the following wage and benefit contract functions:

$$
\begin{aligned}
& W=\overline{\bar{I}} \\
& b=W^{R}-\frac{\left(e^{\ell}-1\right) \overline{\bar{I}}}{\varphi e^{\ell}+(1-\varphi)}<b^{*}, \text { and } \\
& B=\frac{e^{\ell} \overline{\bar{I}}}{\varphi e^{\ell}+(1-\varphi)}-W^{R}>B^{*},
\end{aligned}
$$

where asterisks denote the first-best values. Equation (13b) indicates that unemployment benefits in the ORC LAYOFF are less than in the FB LAYOFF contract, and (13c) that severance pay is greater. Summarizing:

Proposition 2: Under ORC and a logarithmic utility function--if it is optimal to accept a reemployment job offer, $\mathrm{UI}$ benefits are lower and severance pay is higher than in the first-best model.

Above the critical $\varphi$ threshold that makes layoffs optimal, consumption and the underlying contract parameters vary systematically with reemployment probabilities in plausible ways. When reemployment is less likely, the optimal ORC LAYOFF contract relies heavily on 
severance pay. As the likelihood of finding another job $(\varphi)$ increases, lump-sum benefits become less important in the second-best ORC package and UI benefits more generous.

GE contracts may be preferred, even to first-best layoff contracts, especially when reemployment prospects are low ( $\varphi$ small). If layoffs contracts must be redesigned to avoid search moral hazard problems, then GE contracts will be preferred over a wider range of $\varphi$-excessive labor hoarding will occur. This effect is illustrated numerically in Section VI.

\section{Private (Employer) Information, Firing Costs, and Layoff Moral Hazard}

Employers also hold private information that is not in their interests to divulge under the terms of the first-best contract, for example information on demand conditions. Unlike temporary separation risk, which can be monitored cheaply through experience rating of claims behavior, permanent separations are often precipitated by large demand shocks and by plant closings perhaps unique in the firm's experience. Stock markets appear to be surprised by firm plant-closing announcements, and one could expect that workers and insurers are as well. ${ }^{19}$ This private information limits the firm's ability to reinsure with third parties, and simultaneously limits its ability (credibility) to promise its workers generous selffinanced separation benefits. Formally denote this information restriction as:

\section{Asymmetry Assumption 2: Only the firm observes its own product demand state.}

In this case the firm must self-finance the separation package, which has potentially important contract implications.

The reporting of demand state is irrelevant under GE, the conditions of which do not vary with demand in this model. ${ }^{20}$ The environmental factors that favor GE contracts (high

\footnotetext{
${ }^{19}$ For empirical evidence of stock price effects of plant closing announcements, see Blackwell, Marr, and Spivey (1990), Gombola and Tsetsekos (1992), and Clinebell and Clinebell (1994). Hallock (2009, p.85, Table 2) reports that the impact of layoff announcements on stock prices varies with economic conditions, and was substantial during the 1970s and 000s, modest in the 1980s, and nonexistent in the 1990s. Plant closings as opposed to layoffs for other reasons appeared to have no additional stock market effect.

20 If work hours choice was continuous, work hours would normally vary over business conditions (and productivity) in the GE contract.
} 
productivity in the contracting firm and bleak prospects outside it) eliminate any incentive to misreport. Under LAYOFF, however, the firm may have an incentive to misreport the low demand state as high, inducing the worker to work in the low demand state. This is the firing cost problem noted in the mandated severance pay literature.

With fully rational voluntary exchange, the worker will recognize the moral hazard problem embedded in LAYOFF and demand either GE or a restructured LAYOFF. To insure truthful reporting of the low demand state by the risk neutral firm following layoff, the net cost of retaining a worker in the low demand state $\left[W_{1}-\theta v\right]$ must equal or exceed expected payouts to laid-off workers $[B+(1-\varphi) b]$ :

$$
W_{1}-\theta v-[B+(1-\varphi) b] \geq 0
$$

or in consumption terms:

$$
\theta v-\varphi W^{R}-C_{1}+\varphi C_{2}+(1-\varphi) C_{3} \leq 0
$$

Denote these two forms, (14a) and (14b), as the Firing Cost Constraint (FCC). At the firstbest values, the employer has no incentive to respond truthfully that the bad state has occurred if:

$$
\theta v-\varphi W^{R}>0
$$

In the absence of reemployment possibilities $(\varphi=0)$, the employer will never report realization of the bad state truthfully under the first-best contract. If reemployment prospects are high, the expected cost of the separation package is smaller and first-best policy parameters may not induce misreporting.

The optimal contract emerges from maximization of the worker's expected utility subject to (i) the firm's zero expected profit constraint:

$$
\rho v-\rho W_{1}-(1-\rho)[B+(1-\varphi) b]=0,
$$

which in consumption terms is:

$\rho v+(1-\rho) \varphi W^{R}-\rho C_{1}-(1-\rho) \varphi C_{2}-(1-\rho)(1-\varphi) C_{3}=0$,

and (ii) the firing cost constraint (Equation 14b), if binding. 
The corresponding Lagrangian $(\mathcal{L})$ is:

$$
\begin{aligned}
\mathcal{L}=\rho u\left(C_{1}\right) & +\varphi u\left(C_{2}\right)+(1-\rho)\left[(1-\varphi)\left\{u\left(C_{3}\right)+\ell\right\}\right] \\
+\lambda[\rho v & \left.+(1-\rho) \varphi W^{R}-\rho C_{1}-(1-\rho) \varphi C_{2}-(1-\rho)(1-\varphi) C_{3}\right] \\
& +\mu\left[\theta v-\varphi W^{R}-C_{1}+\varphi C_{2}+(1-\varphi) C_{3}\right]
\end{aligned}
$$

The Lagrangian $\mathcal{L}$ is to be optimized with respect to $\mathrm{C}_{1}, \mathrm{C}_{2}, \mathrm{C}_{3}, \lambda$, and $\mu, \mu \geq 0$. The resulting first order conditions are:

$$
\begin{gathered}
\rho\left[u^{\prime}\left(C_{1}\right)-\lambda\right]-\mu=0 ; \\
(1-\rho)\left[u^{\prime}\left(C_{2}\right)-\lambda\right]+\mu=0 \\
(1-\rho)\left[u^{\prime}\left(C_{3}\right)-\lambda\right]+\mu=0, \\
\rho v+(1-\rho) \varphi W^{R}-\rho C_{1}-(1-\rho) \varphi C_{2}-(1-\rho)(1-\varphi) C_{3}=0 \\
\theta v-\varphi W^{R}-C_{1}+\varphi C_{2}+(1-\varphi) C_{3} \geq 0 . \\
\mu \geq 0, \mu \cdot\left[C_{1}-\varphi C_{2}-(1-\varphi) C_{3}-\rho v+\varphi W^{R}\right]=0 .
\end{gathered}
$$

The firing cost constraint will be effective and Expression (17e) an equality as long as $\theta v-$ $\varphi W^{R}>0$. Note that $17 \mathrm{~b}$ and $17 \mathrm{c}$ together yield:

$$
u^{\prime}\left(C_{2}\right)=u^{\prime}\left(C_{3}\right)
$$

which implies

$$
C_{2}=C_{3} \text { and therefore that } b=W^{R} \text {, }
$$

the first-best unemployment insurance benefit.

Although the constraint formally applies to both severance pay and unsubsidized unemployment benefits, only limits on severance benefits emerge in the second-best contract.

Proposition 3: As long as $B^{*}>0$, the firing cost constraint falls entirely on severance pay. 
Note that this not a differential financing issue between severance and unemployment insurance. The unemployed have the lowest consumption outcome, so constrained resources are naturally directed that way to the extent feasible. Basically the second-best FCC contract smooths consumption across outcomes in the low demand state by paying full unemployment benefits and meets the FCC constraint by limiting severance pay.

Equations 17a-c insure that consumption in the high demand state exceeds consumption in the low demand state as long as FCC is effective. An effective FCC induces a wedge between consumption in the high demand state and in the low demand state, but not across outcomes in the low demand state:

$$
C_{1} \geq C_{2}=C_{3} \text {. }
$$

Solving the system yields the following consumption plan:

$$
\begin{aligned}
& C_{1}=\rho v+(1-\rho) \theta v \\
& C_{2}=C_{3}=\rho(1-\theta) v+\varphi W^{R} .
\end{aligned}
$$

Recall that $\rho v+(1-\rho) \theta v \equiv \bar{I}$.

Summarizing:

Proposition 4: As long as $B^{*}>0$, the FCC LAYOFF contract is characterized by (i) equality of consumption among layoff outcomes (unemployment or reemployment), and (ii) consumption inequality between the high demand outcome and the two low demand outcomes, with consumption higher in the high demand outcome.

If an otherwise complete separation contract is constrained by the firing cost constraint, contract provisions take the form (as long as $B^{*}>0$ ):

$$
\begin{aligned}
& W_{1}=\bar{I}, \\
& B=\rho(1-\theta) v-(1-\varphi) W^{R}, \text { and } \\
& b=W^{R}
\end{aligned}
$$

where $\bar{I}=\rho v+(1-\rho) \theta v$. 
"Firing cost" distortions arise in private, voluntary separation plans; excess labor hoarding (the GE contract) is induced by employer-financed separation costs. ${ }^{21}$ The FCC LAYOFF contract limits severance payments more severely the milder the productivity decline in the bad state (the larger $\rho$ ). ${ }^{22}$ Of course the milder the productivity decline, the more likely it is that the worker prefers a GE contract as a first-best contract. FCC reduces the expected utility value of the LAYOFF contract, but is irrelevant for the GE contract, revealing that the range of conditions over which GE is preferred is larger than in the firstbest. Excessive labor hoarding is more likely.

\section{Double-Sided Moral Hazard: Job Search and Layoff Moral Hazard}

The combination of hidden information problems--worker hidden information on job offers and employer hidden information on labor demand-is likely to induce yet more serious distortions. If both FCC and ORC are effective, the firm faces three constraints in setting contract terms-the two potential incentive compatibility constraints, ORC (Equation 8) and FCC (Equation 14a)—and of course the zero profit constraint (ZPC):

$$
\begin{array}{ll}
u\left(B+W^{R}\right)=u(B+b)+\ell & \text { (ORC) } \\
B+(1-\varphi) b=W_{1}-\theta v & \text { (FCC) } \\
\rho W_{1}+(1-\rho) B+(1-\rho)(1-\varphi) b=\rho v & \text { (ZPC) }
\end{array}
$$

Equivalently posed in consumption terms:

$$
\begin{aligned}
& u\left(C_{2}\right)=u\left(C_{3}\right)+\ell . \\
& C_{1}-\varphi C_{2}-(1-\varphi) C_{3}=\theta v-\varphi W^{R} \\
& \rho C_{1}+(1-\rho) \varphi C_{2}+(1-\rho)(1-\varphi) C_{3}=\rho v+(1-\rho) \varphi W^{R}
\end{aligned}
$$

we can solve directly for $\left(C_{1}, C_{2}, C_{3}\right)$.

Denote layoff contracts that must satisfy both the worker-hidden information constraint (ORC) and the firing cost constraint (FCC) as ORC\&FCC LAYOFF contracts. The

\footnotetext{
${ }^{21}$ The firm has no incentive to contract around the voluntarily supplied severance benefit as it does with government-mandated benefits (in excess of those voluntarily supplied), Lazear (1990).

22 Recall that $\theta$, the low demand productivity parameter, does not affect the LAYOFF contract parameters, only the likelihood that it dominates or is dominated by the GE contract.
} 
two incentive compatibility constraints, when combined with the zero profit constraint, fully determine the three layoff contract parameters $\left(W_{1}, B, b\right)$ or equivalently $\left(C_{1}, C_{2}, C_{3}\right)$. Worker preferences enter the solution only through the incentive compatibiity constraints.

The optimal contract shifts insurance payouts from unemployment insurance to severance pay in order to induce revelation of reemployment offers (ORC). The form and overall magnitudes of the offsets are limited however by FCC, which induces a reduction in severance pay. If the worker is to reveal job offers and the firm the demand state, the consumption differential between separated workers who find work and those who do not must be maintained, but the separation package must be less generous in total.

Consider the logarithmic case. If both the ORC and FCC constraints are effective, the three constraints together yield closed form solutions for consumption:

$$
\begin{aligned}
& C_{1}=\bar{I}, \\
& C_{2}=\frac{e^{\ell} \tilde{I}}{\varphi e^{\ell}+(1-\varphi)}, \text { and } \\
& C_{3}=\frac{\tilde{I}}{\varphi e^{\ell}+(1-\varphi)},
\end{aligned}
$$

where $\bar{I}=\rho v+(1-\rho) \theta v$ and $\tilde{I}=\rho(1-\theta) v+\varphi W^{R}{ }^{23} \quad$ The corresponding contract parameters are:

$$
\begin{aligned}
& W=\bar{I} \\
& B=\frac{e^{\ell} \tilde{I}}{\varphi e^{\ell}+(1-\varphi)}-W^{R}, \text { and } \\
& b=W^{R}-\frac{\left(e^{\ell}-1\right) \tilde{I}}{\varphi e^{\ell}+(1-\varphi)} .
\end{aligned}
$$

A casual comparison of consumption under the ORC\&FCC contract, 22(a)-(c) and consumption under ORC contracts, (21a-21c), and FCC contracts, (18a-18b), makes clear the simplicity of the jointly constrained contract. ORC requires a positive wedge between reemployment consumption $\left(\mathrm{C}_{2}\right)$ and unemployment consumption $\left(\mathrm{C}_{3}\right)$ to offset the

${ }^{23}$ Note the different income measures in 22(a) and in 22(b) and 22(c). 
additional leisure among the unemployed, and FCC requires a limit on expected total separation benefits relative to wages in the good state. If FCC is effective, the expected benefit layouts are smaller, but the $\mathrm{C}_{2} / \mathrm{C}_{3}$ ratio $\left(e^{\ell}>1\right)$ is maintained:

$$
\rho(1-\theta) v+\varphi W^{R}-\left[\rho v+(1-\rho) \varphi W^{R}\right]=\rho\left[\varphi W^{R}-\theta v\right]<0 .
$$

Consider:

Proposition 5: Under a logarithmic utility function, the imposition of an effective FCC on an effective ORC will lead (i) to a reduction in consumption of both reemployed and unemployed layoffs $\left(\mathrm{C}_{2}\right.$ and $\left.\mathrm{C}_{3}\right)$, and (ii) a reduction in severance benefits and an increase in unemployment benefits.

This proposition follows immediately from subtraction of the consumption and contract parameter measures under joint ORCFCC (Equation sets 22a-c and 23a-c respectively) and under ORC alone (Equation sets 21a-c and 13a-c respectively) and the effective FCC condition (Inequality 14a):24

$$
\theta v-\varphi W^{R}>0
$$

\section{A Numerical Example}

A numerical example illustrates the impact of the informational constraints on consumption or adequacy and the contract terms that will implement the consumption targets. Assume again the logarithmic consumption utility function:

$$
\begin{array}{ll}
U=\ln (C) & \text { if employed; } \\
U=\ln (C)+\ell, \quad \ell>0, & \text { if unemployed. }
\end{array}
$$

with a leisure utility parameter $(\ell)$ of $0.35 .^{25}$ Assume further that the contract workers is faced with a probability $\rho=0.85$ of realizing the good state, with good-state productivity normalized at one consumption unit $(v=1)$. The productivity parameter in the contract firm $(\theta)$ is 0.5 if retained and the reemployment wage $\left(W^{R}\right)$ is 0.7 if laid off and reemployed. The full set of parameter assumptions is found in Table 1.

$<$ Table 1>

\footnotetext{
24 Note that (14a) reduces to (14a') under ORC values as well as first-best values.

25 This would require that consumption in the unemployed case be no more than 70 percent of consumption in the reemployment case to satisfy the offer revelation constraint.
} 
Outcomes are easily derived in the first-best world. Consumption under the GE contract is not dependent on spot market conditions $\left(\varphi, W^{R}\right)$ and in this numerical example is 0.925, expected productivity. Consumption under the LAYOFF contract does depend on spot market conditions $\left(\varphi, W^{R}\right)$; layoffs become more attractive as the likelihood of securing the next job $(\varphi)$ increases. At $\varphi=0.55$, at which the layoff contract dominates, ${ }^{26}$ consumption is:

$$
\left(C_{1}, C_{2}, C_{3}\right)=(0.908,0.908,0.908) \text {, }
$$

which can be secured with the contract terms:

$$
\left(W_{1}, \mathrm{~B}, \mathrm{~b}\right)=(0.908,0.208,0.7),
$$

Table 1, Column 2.

Consumption is equal across outcomes (0.908), with severance benefits of 0.208 and unemployment benefits of 0.7 (which of course is equal to $W^{R}$ ). The traditional unemployment insurance replacement rate $\mathrm{RR}(\mathrm{UI})$ is a misleading $77 \%\left(\frac{b}{W_{1}} * 100 \%\right)$ even though consumption is equal across states, so the generalized replacement rate $R R(J D I)$ is $100 \%\left(\frac{C_{3}}{C_{1}} * 100 \%\right)$. The plan structure is illustrated as FB in Figures $2 \mathrm{~A}$ and $2 \mathrm{~B}$.

\section{$<$ Figure 2>}

Consider now the impact of limited information. In the highly plausible case that the firm cannot track the job search decisions of laid off workers, the offer revelation constraint (ORC) would be effective. The resulting inefficient LAYOFF contract pushes up the critical threshold at which ORC LAYOFF comes to dominate the GE contract modestly, to $\varphi^{C}=$ 0.515 (implying excess labor hoarding of eight percent), so the layoff contract remains preferred at the hypothetical $\varphi=0.55$ of this example. The consumption levels across outcomes under ORC differ substantially:

$$
\left(C_{1}, C_{2}, C_{3}\right)=(0.908,0.738,1.047)
$$

\footnotetext{
26 The GE contract is preferred to the FB LAYOFF model for: $\varphi<\varphi^{C}=0.475$ The critical phi $\left(\varphi^{C}\right)$ at which $G E$ is no longer preferred declines to 0.40 if $W^{R}=0.75$, and 0.345 if $W^{R}=0.80$.
} 
with ORC met by reducing consumption of the unemployed below the prior wage and increasing the consumption of the reemployed above the prior wage, Table 1, Column 3 and Figure $2 \mathrm{~A}$. The generalized replacement rate for the unemployed worker in this case falls to $R R(J D I)=\frac{0.738}{0.908} * 100 \%=81 \%$.

The Offer Revelation Constraint (ORC) weighs heavily on unemployment benefits: the second-best LAYOFF contract that will implement the consumption outcomes above is:

$$
\left(W_{1}, B, b\right)=(0.908,0.347,0.391)
$$

Figure 2B. Relative to the first-best layoff contract, unemployment benefits are 44 percent lower while severance pay is 88 percent higher. The standard replacement rate would register a misleading 43 percent $\left(R R(U I)=\frac{b}{W 1} * 100 \%=\frac{0.391}{0.908} * 100 \%=43 \%\right)$.

If firm demand conditions are observed only by the firm, the worker will insist that the contract reflect that reality. The FCC LAYOFF contract is superior to the GE contract for $\varphi>$ 0.505, implying a 6 percent increase in the GE range because of this layoff contract inefficiency. ${ }^{27}$ At $\varphi=0.55$, of course the LAYOFF contract is superior and consumption levels across outcomes are:

$$
\left(C_{1}, C_{2}, C_{3}\right)=(0.925,0.81,0.81)
$$

Table 1, Column 3, and Figure 2A. The generalized replacement ratio is now $R R\left((J D I)=\frac{C_{3}}{C_{1}} * 100 \%=88 \%\right.$.

The FCC LAYOFF contract that will implement this consumption package is:

$$
\left(W_{1}, B, b\right)=(0.925,0.11,0.7)
$$

Severance benefits are reduced by almost one half from the first-best 0.208 , while unemployment benefits are unaffected. Table 1, Column 4 and Figure 2B. The financial

\footnotetext{
27 The FCC constraint is not effective for $\varphi \geq 0.714$. Recall that the FCC constraint is financial, spanning the circumstances under which the firm has an incentive to treat workers as if the good state had emerged, which itself is costly if it has not. If the expected separation expenditures fall sufficiently, as they will if rehire probabilities are low, then the firm will not disguise the bad state signal.
} 
constraint leads to limited resources, with the unemployed having the greatest need. The traditional replacement ratio is now:

$$
R R\left((U I)=\frac{b}{W_{1}} * 100 \%=\frac{0.7}{0.925} * 100 \%=78 \%,\right.
$$

only slightly less than the generalized measure in this case.

Consider the joint constraints. In this example, the joint ORC\&FCC LAYOFF contract is superior to the GE contract for $\varphi>0.53$. The consumption profile when all constraints are effective is:

$$
\left(C_{1}, C_{2}, C_{3}\right)=(0.925,0.934,0.659) \text {. }
$$

and the contract provisions:

$$
\left(W_{1}, B, b\right)=(0.925,0.234,0.424) \text {. }
$$

Table 1, Column 5 and Figures $2 \mathrm{~A}$ and 2B. Consumption of the unemployed is 9 percent less than among those retained. The generalized replacement rate for the unemployed worker under these two constraints is $71 \%: R R(J D I)=\frac{C_{3}}{C_{1}} * 100 \%=\frac{0.659}{0.925} * 100 \%=$ $71 \%$, the traditional replacement rate is $46 \%: R R(U I)=\frac{b}{W_{1}} * 100 \%=\frac{0.424}{0.925} *$ $100 \%=46 \%$. The addition of FCC to the ORC constraint induces a shift away from severance benefits of 33 percent, and a slight increase in unemployment benefits (of 8.4 percent). The net result of the additional constraint is a further drop of 11 percent in the consumption of the unemployed (from ORC levels).

\section{Reforming the "Unemployment Insurance" System}

A fundamental regularity of the U.S. labor market is that the labor market opportunities of displaced workers fade with service or tenure $(\tau)$. Not only are long-tenured workers less likely to find the next-job quickly $\left(\frac{d \varphi}{d \tau}<0\right)$, the jobs they find are likely to be at 
lower wages than their pre-displacement jobs $\left(\frac{d W^{R}}{d \tau}<0\right) .{ }^{28}$ This reality has important implications for how optimal contracts, both first and second-best, vary with tenure.

Job displacement insurance must consider wage insurance, which practically speaking means severance pay, as well as unemployment insurance benefits. The first-best model, as well as various second best models, calls for larger severance benefits with worker service in order to cover ever increasing expected reemployment wage losses, Figure $1 \mathrm{~b}$. Severance pay tends to be structured to reflect that, both in voluntary plans in the U.S. and in mandated plans worldwide. Using data drawn from Holzmann et al (2012), Figure 5 illustrates the distribution of mandated benefits world-wide at five years and twenty years of service. Although there are flat rate mandates, most mandates are consistent with a "number of weeks of pay per year of service" model. The modal benefit level at five years of service is about 10 weeks of pay, or two weeks per year of service, and the average expansion factor between five years and twenty is only slightly less than four.

\section{$<$ Figure 5>}

The first-best model would have unemployment benefits vary with reemployment wages, and specifically decline as expected reemployment wages decline with tenure. ${ }^{29}$ The prescription of declining $\mathrm{UI}$ benefits with tenure is even more obvious in the search moral hazard model, with the decreasing benefits with service mirroring the decline in reemployment wage. Actual unemployment insurance benefit levels in the U.S. are earnings- but not service-connected. Benefit levels do vary with the duration of benefit receipt, often as a step (down) function to zero, but not by worker tenure level. Internationally age is a more frequent conditioning factor for maximum unemployment benefit duration, usually in an attempt to bridge "gaps" until retirement benefits begin, but again not for benefit levels.

\footnotetext{
${ }^{28}$ In multi-period contracts, older workers are more likely to retain their jobs in the first place $\left(\frac{d \rho}{d \tau}>0\right)$ because of the last-in-first-out policies common in both unionized and nonunionized workplaces. 29 The combination of unemployment insurance benefits and severance completely covers total earnings losses for those who cannot find reemployment.
} 
The lack of adjustment for service in the UI benefit formula is problematic if search moral hazard is a concern. If the level is set appropriate to the short-tenured unemployed worker (high UI benefits and low severance pay), the benefit level will systematically discourage rehire among long-tenured workers with lower reemployment prospects relative to the pre-layoff wage. In this simple model, senior workers would not accept reemployment offers. Conversely if the benefit level is set to insure that long-service workers return to work at the lower reemployment wage if asked, then the short-tenured workers will be only partially insured against unemployment spells.

The likelihood of layoff moral hazard (firing cost) problems would of course rise with tenure in the first-best package, because all losses are covered, and these losses-both from unemployment spells and lower reemployment wages--grow with tenure. The key value is the expected separation benefit expenditures conditional on being displaced, where $E(S E P B E N)=B+(1-\varphi) b$ and first-best $E(S E P B E N)$ grows with tenure. Either the worker will choose a layoff contract with diminished severance benefits that will insure the firm will reveal the demand state or skip layoffs and accept in its stead a guaranteed employment contract that does not require the firm to reveal its demand state.

One can easily design a subsidy that would eliminate FCC as an effective constraint. If unemployment benefits and severance benefits are mandated at first-best levels, a sufficiently large subsidy (or a shift to a non-user fee tax finance) to either expected unemployment benefits or severance benefits or some combination of the two would eliminate the firing cost constraint. In the numerical example, the firm would lay off workers in first-best circumstances with mandated first-best benefits as long as the government redirects 9.5 percent of total expected separation costs from "user cost" financing (financing linked to actual separation expenditures) to more general financing. ${ }^{30}$

30 This calculation assumes that the subsidy is financed by a lump sum payroll tax of 0.5 percent of the value of production in the high demand state $(0.05 \mathrm{v})$. 


\section{Conclusion}

A one period contracting model of job separation with the possibility of reemployment elsewhere is developed and used to frame the discussion of the ideal job displacement insurance package. Earnings losses arise from unemployment spells and reemployment wage losses. Workers can insure against job displacement losses either by entering guaranteed employment (labor hoarding) contracts or layoff contracts with a separation benefit package of unemployment benefits and wage insurance. Wage insurance is rarely if ever observed, but severance benefits, which are common, can be seen as scheduled wage insurance. In this two dimensional insurance package, a generalized replacement rate is needed to measure insurance adequacy-the sum of severance pay and UI benefits for the unemployed, or in the absence of other assets, total consumption of the unemployed relative to those who were not laid off. In the additively separable utility model used here, the ideal generalized job displacement replacement rate is 100 percent, with unemployment benefits equal to the reemployment wage and severance pay covering the difference.

Partial unemployment benefits may arise if search moral hazard limits the generosity of $\mathrm{UI}$ benefits. If the firm (authorities in a government model) cannot monitor the unemployed worker's wage offers, unemployment benefits must be sufficiently less than reemployment wages so that the worker is not better off remaining unemployed. The magnitude of the wedge between benefits and reemployment earnings is fixed by this imperative, but the location of the wedge relative to the wage of the worker who did not experience a layoff depends on market conditions. If most laid off workers cannot find employment, total consumption (UI benefits plus severance pay) will optimally approach initial pre-layoff wages. If most find work, reemployment wages.

A second potential concern is "firing costs," which we label here layoff moral hazard to draw the parallel with search moral hazard. Layoff moral hazard refers to the incentive of the firm to retain workers in low demand states (limit layoffs) because of the expected cost of the separation package. Some labor hoarding is optimal in the absence of moral hazard concerns-when for example workers as well as firms can monitor demand states and 
commit to contracts based on that monitoring—but may become excessive when information is limited and firms adjust strategically. The design of the constrained program is straightforward; limited separation pay resources will be devoted solely to the unemployed until the first-best optimal UI benefit is reached (equal to the reemployment wage), after which resources will be channeled to severance pay. In a doubly constrained world (search and layoff moral hazard) the search moral hazard wedge between the unemployed and the never-laid-off will be maintained and aggregate separation benefits increased or decreased to meet the layoff moral hazard constraint.

Well known regularities in job displacement earnings losses with job tenure suggest obvious reforms of the "unemployment insurance" system. Long-tenured displaced workers typically receive lower wages upon reemployment, which has implications for both severance benefits. Severance benefits should be higher than those offered short-tenured workers and unemployment insurance benefits should be lower. If $\mathrm{UI}$ benefits are fixed at a level optimal for short-tenured workers, they will systematically induce high tenured, displaced workers, with lower reemployment wage prospects, to ignore otherwise attractive wage offers.

More generally the reemployment labor markets $\left(\varphi, W^{R}\right)$ that displaced workers confront, and therefore the ideal separation benefit package they should receive $(B, b)$, will vary across national economies. Within any economy, the reemployment market will also vary across industries, education levels, and across points in the business cycle. If we are to understand better the nature of job displacement insurance, we need to characterize these regularities carefully. There is no one-size-fits-all job displacement insurance plan. 


\section{REFERENCES}

Azariadis, Costas. 1975. "Implicit Contracts and Underemployment Equilibria," Journal of Political Economy, 83 (December): 1183-1202.

Baily, Martin Neil. 1977. "Unemployment Insurance.as Insurance for Workers" Industrial and Labor Relations Review 30 (July): 495-504.

Baily, Martin Neil, Gary Burtless, and Robert E. Litan. 1993. Growth with Equity: Economic Policymaking for the Next Century, Washington, DC.: 110-141.

Blackwell, David W.; M. Wayne Marr, and Michael F. Spivey. 1990. "Plant-Closing Decisions and the Market Value of the Firm Source," Journal of Financial Economics v26.2 (August): 277-88.

Blanchard, Olivier J., and Jean Tirole. 2008. "The Joint Design of Unemployment Insurance and Employment Protection: A First Pass," Journal of the European Economic Association v.6(1) March: 45-77.

Buechtemann, C.F. ed. 1992. Employment Security and Labor Market Behavior: Interdisciplinary Approaches and International Evidence, Ithaca, NY: ILR press, Cornell University.

Bureau of Labor Statistics (U.S. Department of Labor). 2012. Worker Displacement: 20092011. BLS news release USDL-12-1719.

Clinebell, Sharon K; and John M. Clinebell. 1994. "The Effect of Advance Notice of Plant Closings on Firm Value, Journal of Management; v.20.3 (Fall): 553-565.

Fallick, Bruce C. 1996. "A Review of the Recent Empirical Literature on Displaced Workers." Industrial and Labor Relations Review, v.50.1 (October): 5-16.

Farber, Henry S. 2004 Job Loss in the United States, 1981-2001 Accounting for Worker Well-being, Research in Labor Economics, v.23. 69-117.

Farber, Henry S. 2011. "Job Loss in the Great Recession: Historical Perspective from the Displaced Workers Survey, 1984-2010," IZA DP No. 5696. May 2011.

Fredriksson, Peter, and Bertil Holmlund. 2006. "Improving Incentives in Unemployment Insurance: A Review of Recent Research," Journal of Economic Surveys, vol.20.3: 357- 386.

Gombola, Michael J.; and George P. Tsetsekos. 1992. "The Information Content of Plant Closing Announcements: Evidence from Financial Profiles and the Stock Price Reaction," Financial Management v21.2 (Summer): 31-40.

Hallock, Kevin F. 2009. "Household Risks: Job Loss and the Fraying of the Implicit Employment Contract," Journal of Economic Perspectives, v. 23.4 (Fall): 69-93.

Heckman, James J., and Carmen Pagés. 2004. "Introduction," in Heckman and Pagés, eds., Law and Employment: Lessons from Latin America and the Caribbean, Chicago, The University of Chicago: 1-107.

Holmlund, Bertil. 1998. "Unemployment Insurance in Theory and Practice," Scandinavian Journal of Economics, 100(1): 113-141.

Holzmann, Robert, Yann Pouget, Michael Weber, and Milan Vodopivec. 2012. "Severance Pay Programs around the World: History, Rationale, Status, and Reforms" In Robert Holzmann and Milan Vodopivec, eds., Reforming Severance Pay: An International Perspective, Washington, DC: World Bank: 17-120.

Hopenhayn, Hugo A. and Juan Pablo Nicolini. 1997. "Optimal Unemployment Insurance," Journal of Political Economy, 105.2 (April): 412-438. 
Jacobson, Louis S., Robert J. LaLonde, and Daniel G. Sullivan, 1993a. "Earnings Losses of Displaced Workers, American Economic Review v.83.4 (September): 685-709. 1993a.

Jacobson, Louis S., LaLonde, Robert J. and Sullivan, Daniel G. 1993b. "Long-term Earnings Losses of High-seniority Displaced Workers." Economic Perspectives 17 (November/ December): 2-20. 1993b.

Karni, Edi, 1999. 2006. "Optimal Unemployment Insurance: A Survey." Southern Economic Journal, 66 (October): 442-65.

Kletzer, Lori G. 1998. "Job Displacement." Journal of Economic Perspectives v12, n1 (Winter): 115-36

Kling, Jeffrey R. 2006 "Fundamental Restructuring of Unemployment Insurance: Wage-Loss Insurance and Temporary Earnings Replacement Accounts," The Hamilton Project, Brookings Institution, Discussion Paper 2006-05 September 2006.

Kuhn, Peter, ed. 2002. Losing Work, Moving On: International Perspectives on Worker Displacement, W.E. Upjohn Institute for Employment Research, Kalamazoo, Michigan.

LaLonde, Robert J. 2007. "The Case for Wage Insurance," Maurice R. Greenberg Center for Geoeconomic Studies at the Council on Foreign Relations http://www.cfr.org/publication/13661/case for wage insurance.html,

Lazear, Edward P. 1990. "Job Security Provisions and Employment," Quarterly Journal of Economics 105 (August), 699-726.

Malcomson, J. 1999. "Individual Employment Contracts," in Orley Ashenfelter and David Card, eds. Handbook of Labor Economics, Vol. IIIB, Chapter 35, North Holland Press pp.2291-2372.

Parsons, Donald O. 1986. "The Employment Relationship: Job Attachment, Work Effort, and the Nature of Contracts" in Orley Ashenfelter and Richard Layard, eds. Handbook of Labor Economics, Vol. II, North Holland Press: 789-848.

Parsons, Donald O. 1996. "Imperfect "Tagging" in Social Insurance Programs," Journal of Public Economics 62: 183-207.

Parsons, Donald O. 2000. "Wage Insurance: A Policy Review," in Research in Employment Policy, 2: 119-140.

Parsons, Donald O. 2012. "Mandated Severance Pay and Firing Cost Distortions: A Critical Review of the Evidence," Chapter 3 in Robert Holzmann and Milan Vodopivec, eds., Reforming Severance Pay: An International Perspective, Washington, DC: World Bank, 2012, 121-157.

Parsons, Donald O. 2013. "Understanding Severance Pay," Cuadernos de Economía (Spanish Journal of Economics and Finance) Elsevier. v.36, no, 106 Sept-Dec, 2013: 155-165. Draft available as "Understanding Severance Pay," IZA Working Paper 7641. http://ftp.iza.org/dp7641.pdf.

Parsons, Donald O., 2015. "Job Displacement Insurance" in James Wright, ed. International Encyclopedia of the Social and Behavioral Sciences, 2nd edition, Vol 12. Oxford: Elsevier. pp. 819-832. March 2015. Draft available at http://ftp.iza.org/dp8223.pdf

Parsons, Donald O. 2016. "Moral Hazard Concerns in First-best Unemployment insurance Contracts," George Washington University. (February).

Rosen, Sherwin. 1985. "Implicit Contracts: A Survey," Journal of Economic Literature 23 (September): 1144-1175.

Salanié, Bernard. 2005. The Economics of Contracts: A Primer, Second Edition, MIT Press. 
Shavell, Steven and Laurence Weiss. 1979. "The Optimal Payment of Unemployment Insurance Benefits over Time." Journal of Political Economy 87 (December): 13471362.

Viard, Alan D. 2001. "Optimal Categorical Transfer Payments: The Welfare Economics of Limited Lump-Sum Redistribution," Journal of Public Economic Theory 3 (October): 483-500. 
Table 1

Information Asymmetries and Optimal Layoff Contract Provisions With Consequences for Consumption across States

\begin{tabular}{|c|c|c|c|c|c|}
\hline & & & & & \\
\hline & & & & & \\
\hline & GE & $\begin{array}{c}\text { FIRST } \\
\text { BEST } \\
\text { LAYOFF }\end{array}$ & ORC & FCC & $\begin{array}{l}\text { ORC/ } \\
\text { FCC }\end{array}$ \\
\hline & (1) & $(2)$ & (4) & (3) & (5) \\
\hline Phi Bounds & & & & & \\
\hline & & & & & \\
\hline$\varphi^{C}$ & NA & 0.475 & 0.515 & 0.505 & 0.535 \\
\hline$\varphi_{2}^{C}$ & NA & NA & & 0.714 & 0.714 \\
\hline$\Phi=0.55$ & & & & & \\
\hline & & & & & \\
\hline W1 (WAGE) & 0.925 & 0.908 & 0.908 & 0.925 & 0.925 \\
\hline $\mathrm{B}(\mathrm{SEV})$ & NA & 0.208 & 0.347 & 0.11 & 0.234 \\
\hline $\mathrm{b}(\mathrm{UI})$ & $\mathrm{NA}$ & 0.7 & 0.391 & 0.7 & 0.424 \\
\hline & & & & & \\
\hline $\mathrm{C}_{1}(\mathrm{EMP})$ & 0.925 & 0.908 & 0.908 & 0.925 & 0.925 \\
\hline $\mathrm{C}_{2}$ (REEMP) & 0.925 & 0.908 & 1.047 & 0.81 & 0.934 \\
\hline $\mathrm{C}_{3}$ (UNEMP) & 0.925 & 0.908 & 0.738 & 0.81 & 0.659 \\
\hline
\end{tabular}

$\mathrm{GE}=$ guaranteed employment (no layoff) LAYOFF

FIRST BEST = full information

ORC $=$ offer revelation constraint

$\mathrm{FCC}=$ firing cost constraint

ORC\&FCC =both offer revelation and firing cost constraints may be effective. MODEL:

$$
\begin{array}{ll}
U=\ln (C) & \text { if employed; } \\
U=\ln (C)+\ell, \quad \ell>0 & \text { if unemployed }
\end{array}
$$

PARAMETERS

$$
\begin{aligned}
& \ell=0.35 \\
& \rho=0.85 \\
& v=1.0 \\
& \theta=0.5 \\
& \sigma=0.7\left(W^{R}=0.7\right) \\
& \varphi=0.55
\end{aligned}
$$

$\varphi^{C}$ GE/FB, GE/ORC, GE/FCC, and GE/FCC\&ORC boundaries.

$\varphi_{2}^{C} \quad$ FCC\&ORC/ORC boundaries. 


\section{FIGURE 1}

THE IMPACTS OF JOB DISPLACEMENT (DWS)

Panel A: Post-Separation (up to three years)

Labor Force Status by Age, Long Tenured Workers Jan 2012

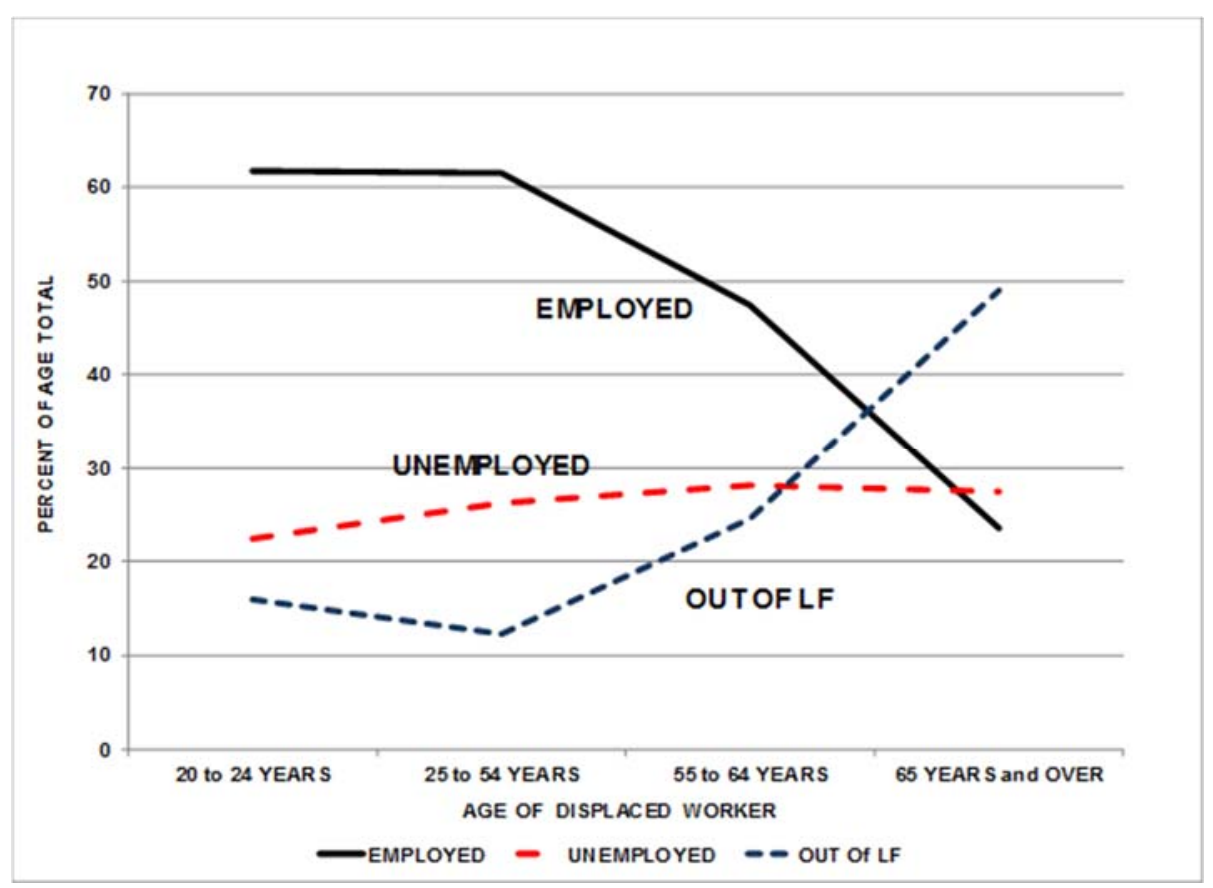

Panel B: Reemployment Wage Effects by Tenure

Full-time to Full-time Employment, 1981-2001

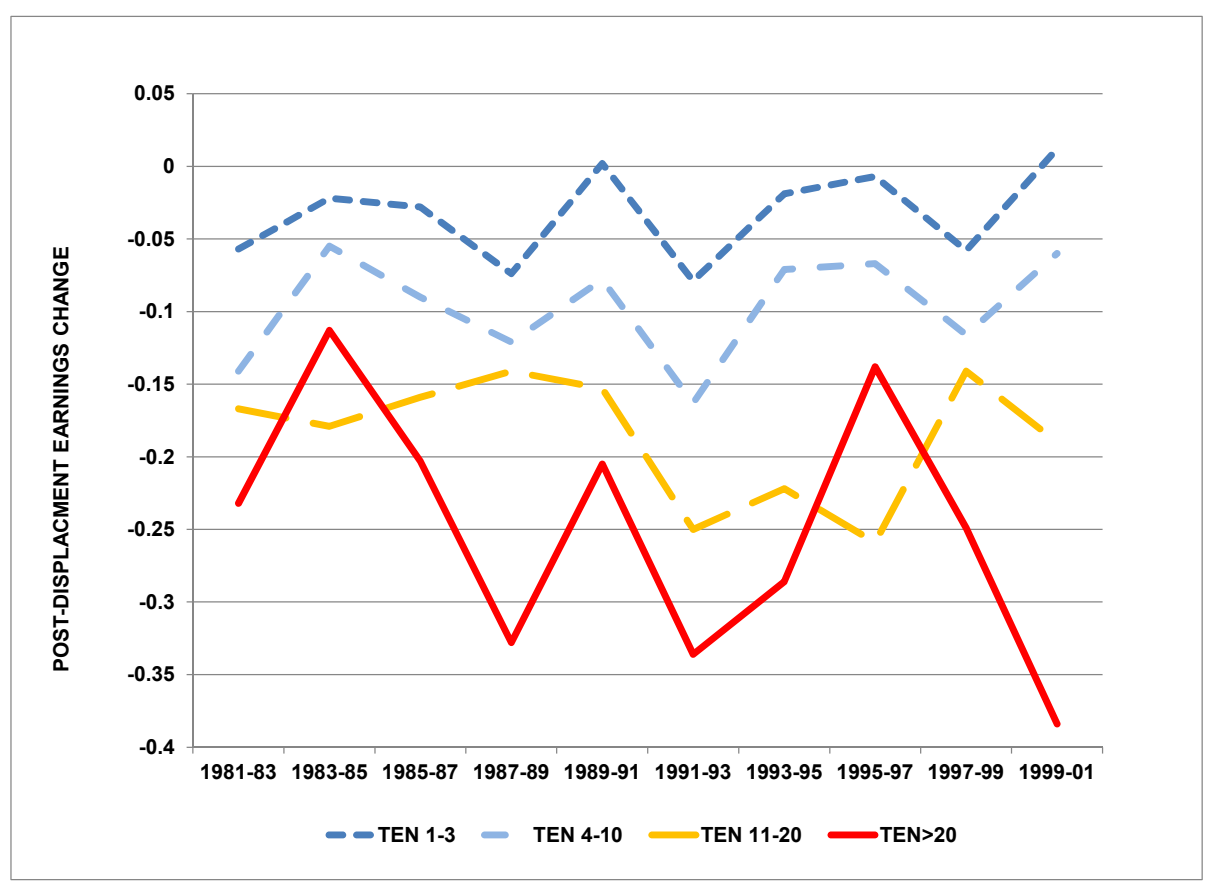


FIGURE 2

CONSUMPTION AND OPTIMAL CONTRACT PROVISIONS ACROSS OUTCOMES By CONTRACT ENVIRONMENT

Panel A: Consumption

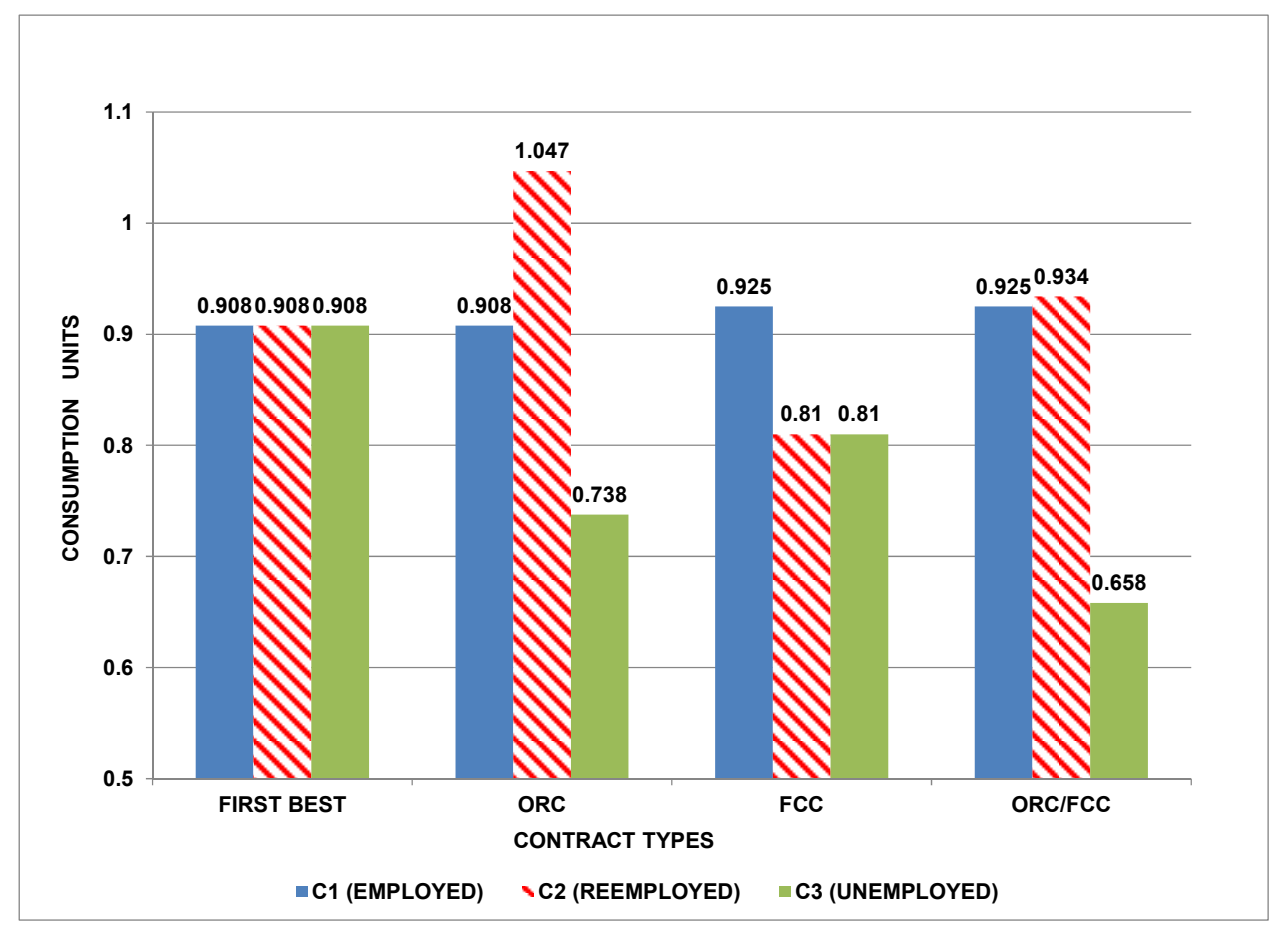

Panel B: Contract Provisions

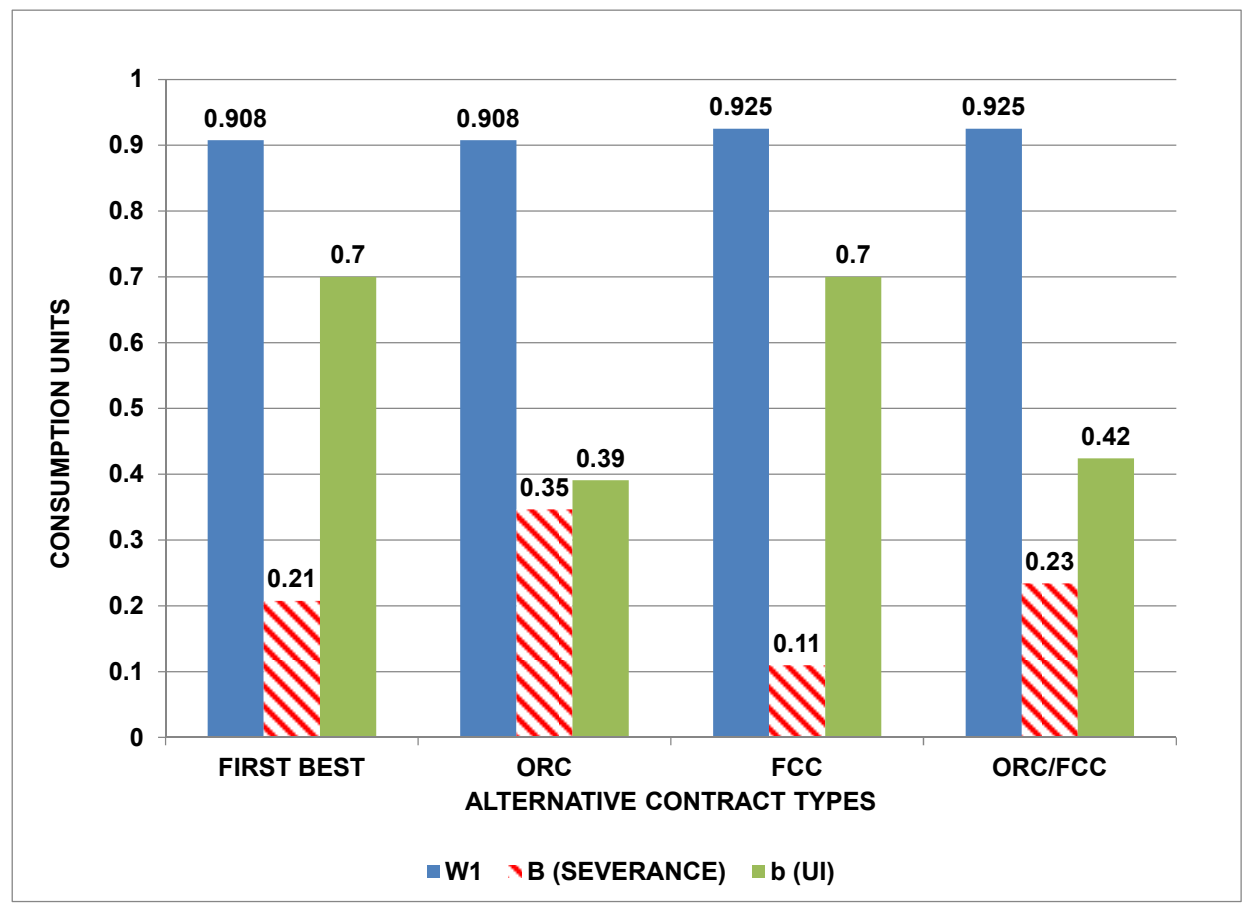


FIGURE 3

CONSUMPTION AND CONTRACT PROVISIONS

AS A FUNCTION OF REEMPLOYMENT PROBABILITY $\varphi$ UNDER SEARCH MORAL HAZARD CONSTRAINT (GE SUPPRESSED)

Panel A: Consumption

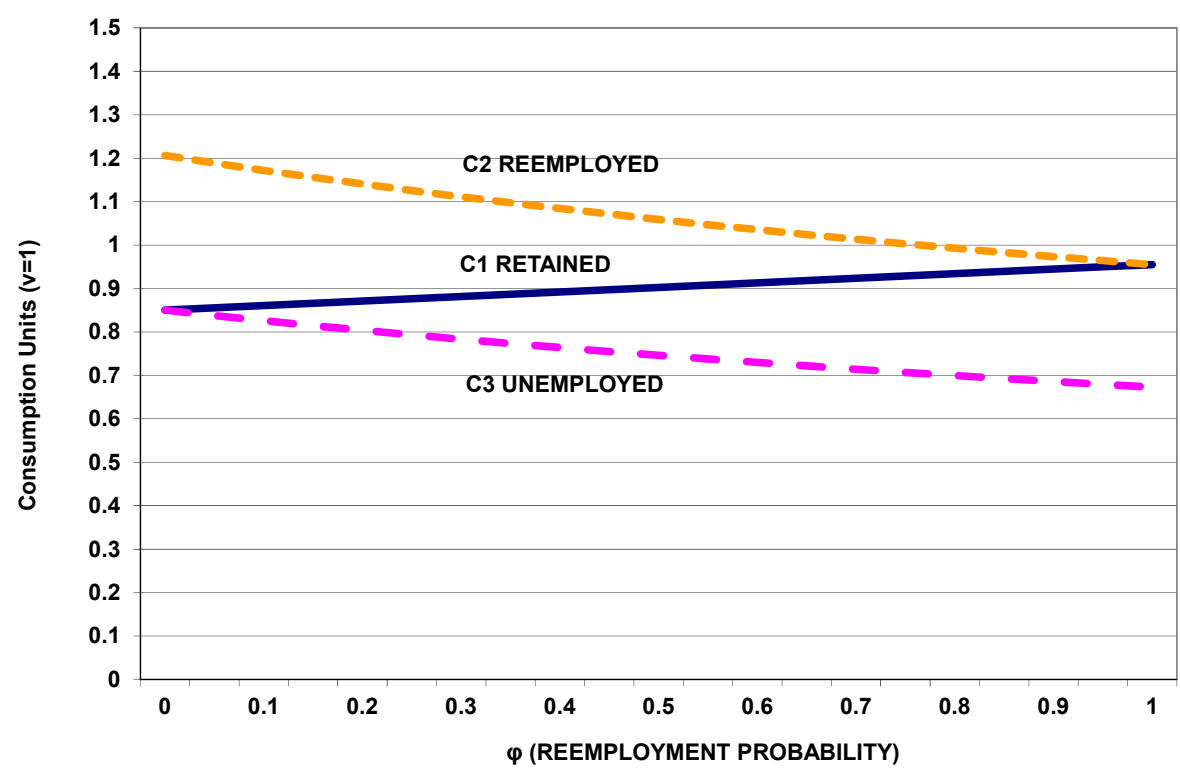

Panel B: Contract Parameters

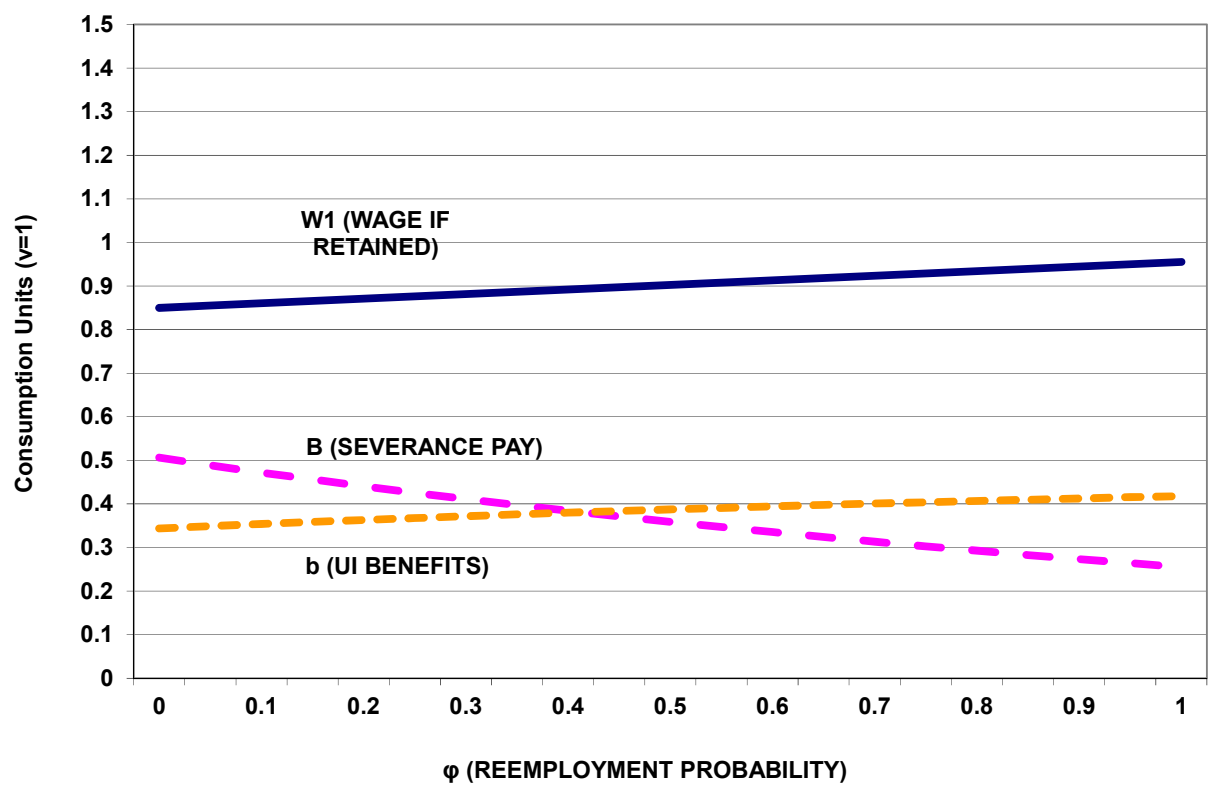


FIGURE 4

CONSUMPTION AND CONTRACT PROVISIONS

AS A FUNCTION OF REEMPLOYMENT PROBABILITY $\varphi$

UNDER SEARCH MORAL HAZARD CONSTRAINT

Panel A: Consumption

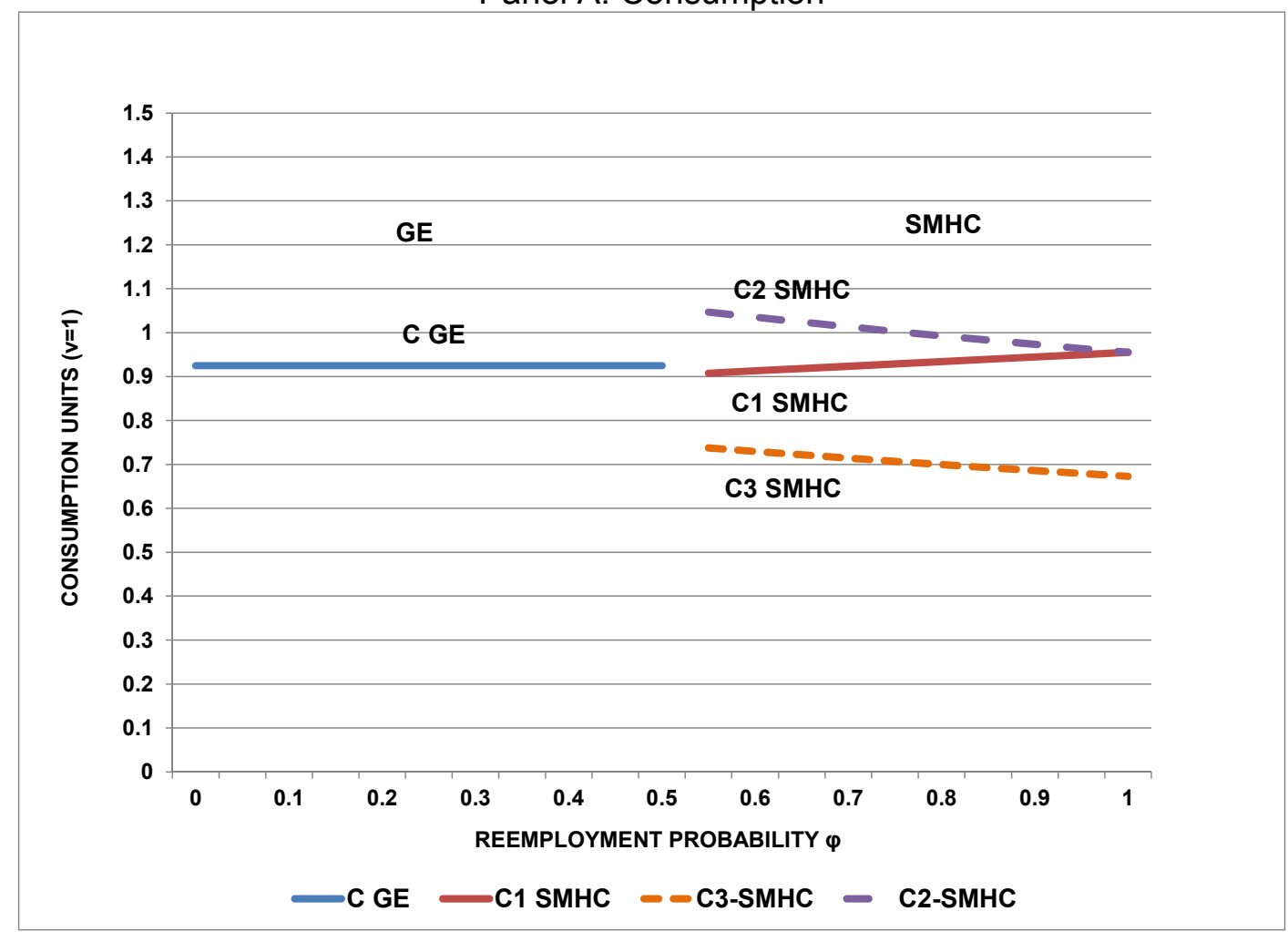

Panel B: Contract Parameters

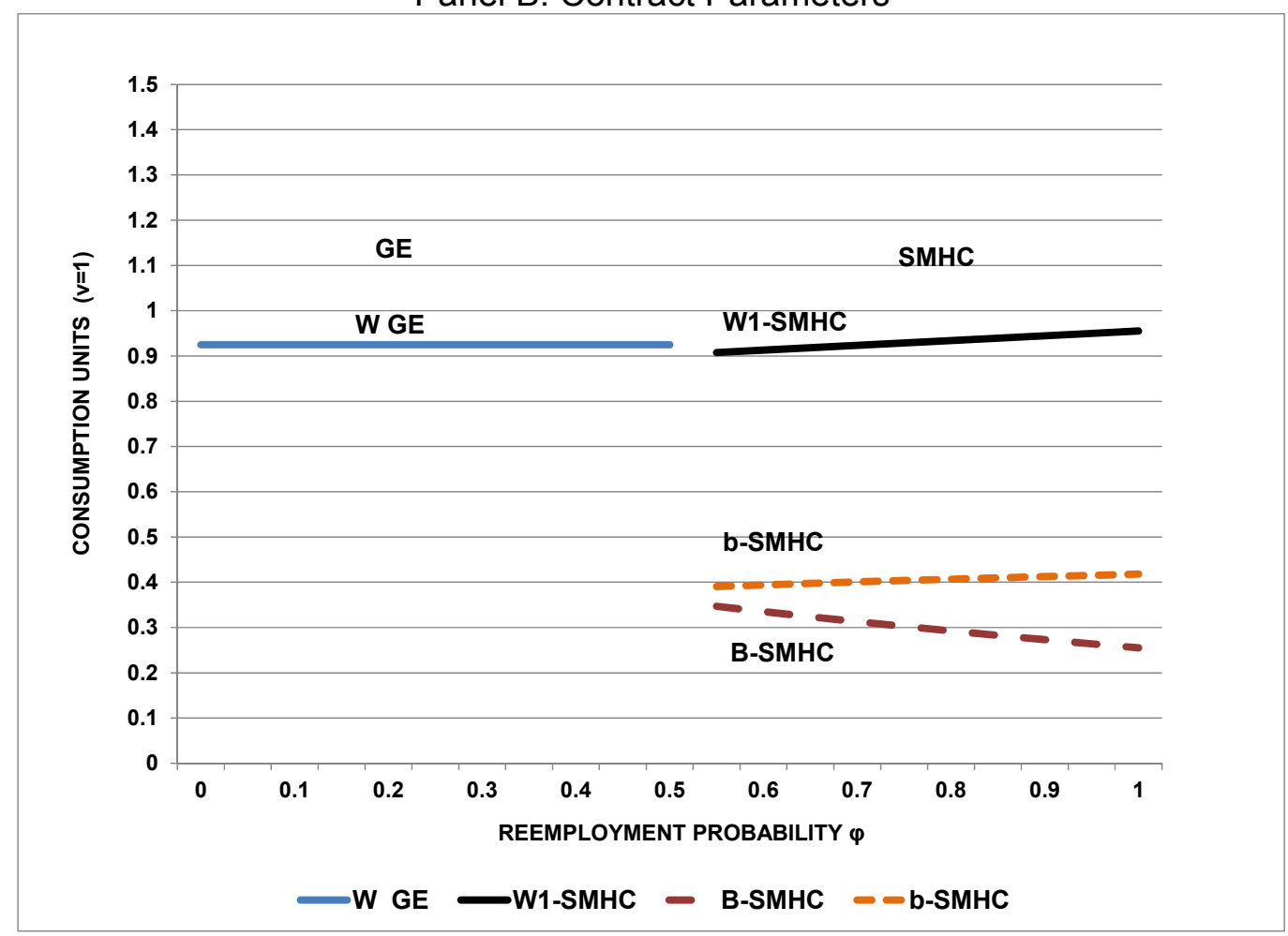


FIGURE 5

SEVERANCE GENEROSITY (WEEKS OF PAY)

AT FIVE AND TWENTY YEARS OF SERVICE MEDIUM AND LARGE COUNTRIES, HOLZMANN ET AL (2012, ANNEX B)

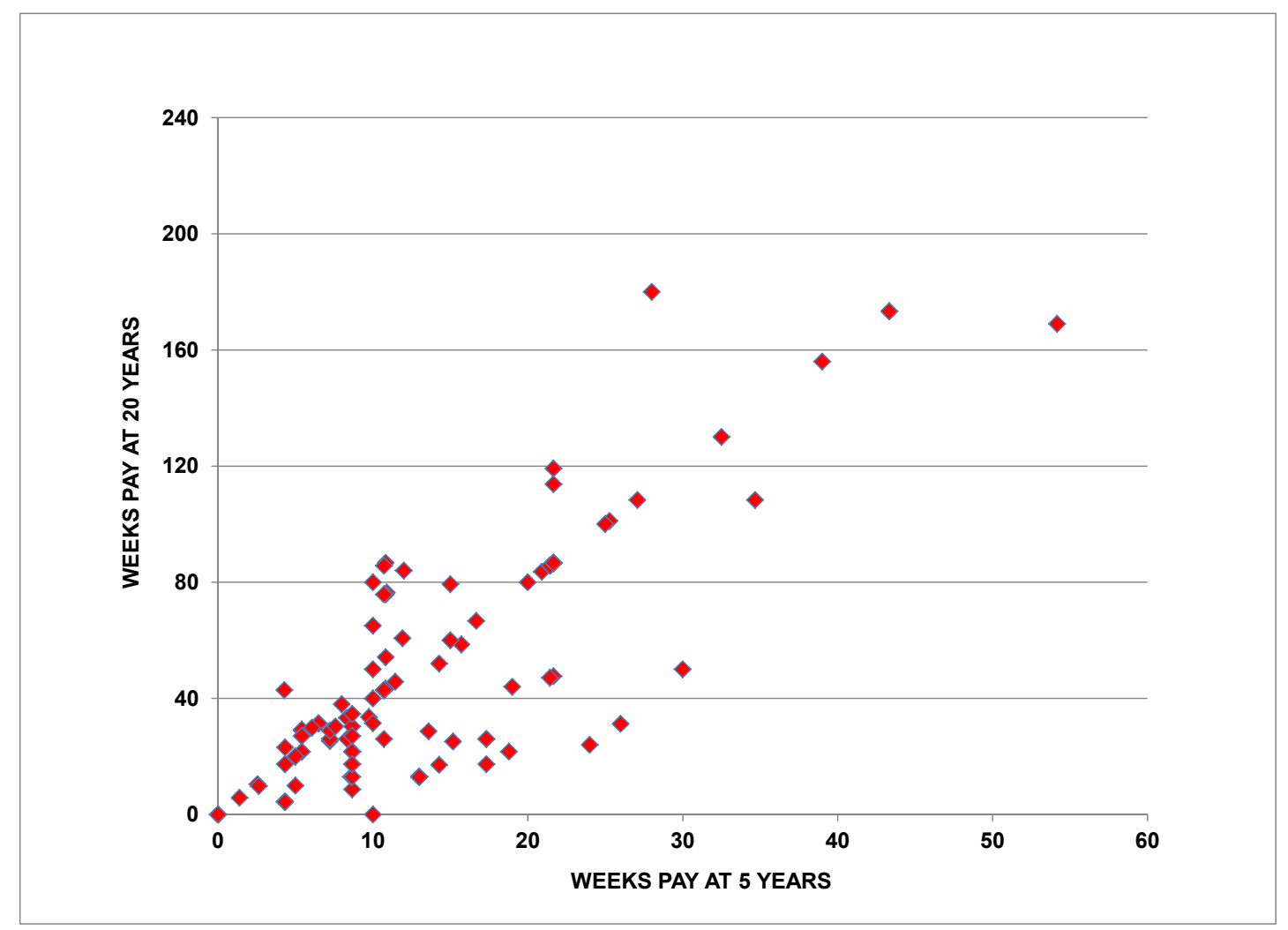

